\title{
Effect of Nitrogen and Potash on Growth of Coriander (Var. Super Midori)
}

\author{
S.P. Mishra ${ }^{*}$, A.K. Padhiary ${ }^{2}$, A. Nandi ${ }^{3}$ and A. Patnaik ${ }^{3}$ \\ ${ }^{1}$ Krishi Vigyan Kendra, Jagatsingpur, Odisha, India \\ ${ }^{2}$ Krishi Vigyan Kendra, RRTTS Campus (OUAT) Chiplima, Sambalpur 768026 Odisha, India \\ ${ }^{3}$ Department of Vegetable Science, OUAT, Bhubaneswar, 751003, Odisha, India \\ *Corresponding author
}

\section{A B S T R A C T}

\begin{tabular}{|l|}
\hline Ke y w o r d s \\
$\begin{array}{l}\text { Coriander (Coriandrum } \\
\text { sativum L.), Nitrogen and } \\
\text { Potash }\end{array}$ \\
\hline Article Info \\
\hline $\begin{array}{l}\text { Accepted: } \\
\text { 04 November } 2018 \\
\text { Available Online: } \\
\text { 10 December } 2018\end{array}$ \\
\hline
\end{tabular}

Keywords

Coriander (Coriandrum Potash

\section{Introduction}

India is known as the "Land of Spices" and is the largest producer, consumer and exporter of spices and spice products. Out of the total sixty three spices grown in India twenty are classified as seed spices with thirty six percent shares in area and seventeen per cent share in production of total spices in India.

It is a challenge for us to modernise technologies with efficient utilization of resources to derive higher production with excellent quality. This required the intervention of technologies that are less environment dependent, capital intensive, with the capacity to improve the productivity and
An experiment entitled " Integrated nutrient management of Coriander variety Super dori" of Tokita seed was conducted in the Department of Vegetable Science, College of A ( phosphorous $(40 \mathrm{~kg} / \mathrm{ha})$ on growth, growth attributing characters of coriander leaves under two sets of experiment i.e. line sowing and broadcasting. It was found that inline sowing the number of day ( 8.25 day) to germinate was lowest in interaction effect of nitrogen and potash $\left(\mathrm{N}_{2} \mathrm{~K}_{2}\right)$. Similarly in broad casting i.e. 8 days in $\mathrm{N}_{1} \mathrm{~K}_{1}$ and $\mathrm{N}_{3} \mathrm{~K}_{3}$. Germination percentage was found maximum in $\mathrm{N}_{2} \mathrm{~K}_{1}(90.78 \%), \mathrm{N}_{3} \mathrm{~K}_{2}(85.83)$ in line sowing \& broadcasting respectively. The height of the plant at 30 days is 17.48 in $\mathrm{N}_{3} \mathrm{~K}_{2}$ treatment under line sowing whereas $18.38 \mathrm{~cm}$ was found in $\mathrm{N}_{3} \mathrm{~K}_{2}$ under broadcasting.

quality of the produce. Coriander (Coriandrum sativum L.) family Apiaceae is an important seed spices cultivated in almost all the states of India for its leaves and seeds.

Coriander is probably one of the five spices used by mankind, having been known as early as $5000 \mathrm{BC}$. Coriander is an annual herb originated in the Mediterranean region is now mainly grown in India (Area 547421ha and production 527390 tonnes). Coriander is largely cultivated as a spice crop both for seed purpose \& leaves purpose in almost all the states on commercial scales like Rajasthan, Andhra Pradesh, Madhya Pradesh, Tamilnadu, Gujarat, Uttar Pradesh, Bihar, Karnataka and Odisha. The farmers of Orissa are growing 
coriander crop in rabi seasaon for leaf\& seed purpose. Various agronomic practices such as application of FYM, INM, IPM, bio-fertilizers and different level of nutrients are more deciding factors along with agronomic manipulation of the existing practices for success of a crop to make it more remunerative.

\section{Materials and Methods}

The field experimental entitled "Integrated nutrient management in coriander Variety "super Midori" was carried out in the experiment plot of the Department of Vegetable Science, OUAT during 201314.The present experiment constitutes six treatments with four replications in Randomized Block design (Factorial). The coriander variety "Super Midori" was sown in the trial field. The detail of the experiment conducted is given below.

Design Layout- Complete Randomized block design (factorial).

Number of Treatment - 6

Number of replications - 4

Number of Trials-2 (line sowing and broadcasting)

Total of number of plots - 24

Plot Size - 1mtx $1.5 \mathrm{mt}$

Spacing - row to row $-10 \mathrm{~cm}$

\section{Line to line - continuous thinly sowing of seeds}

Number of rows per plot - 14

Length of the experimental field $-10.5 \mathrm{mt}$

Width of the experimental field $-5 \mathrm{mt}$

Area of the experimental field $-52.5 \mathrm{~m}^{2}$

Two trial were conducted, one for line showing \& other for broadcasting.

\section{Levels of chemical fertilizers}

$\mathrm{N} 1$ - $50 \mathrm{~kg}$ of Nitrogen/ha.

$\mathrm{N} 2-60 \mathrm{~kg}$ of Nitrogen/ha.

$\mathrm{N} 3-70 \mathrm{~kg}$ of Nitrogen/ha.

$\mathrm{K} 1-50 \mathrm{~kg}$ of Potassium/ha.

$\mathrm{K} 2$ - $60 \mathrm{~kg}$ of potassium /ha.

FYM- @ 20 t/ha.

\section{Details of Treatments}

T1 - N1PK1 - 50:40: 50

T2 - N1PK2-50:40: 60

T3 - N2PK1 - 60:40:50

T4 - N2PK2 - 60:40:60

T5 - N3PK1 - 70:40:50

T6 - N3PK2 - 70:40:60

\section{Results and Discussion}

Days to germination of seeds are tabulated and presented in Table 1 revealed that maximum mean days to seed germination of 8.5 days was recorded in all the treatments. Application of different doses of potash took 8.41 days to germination with $\mathrm{K} 2 \& 8.58 \mathrm{~K} 1$.

However with interaction maximum days to germination (8.75) were found with $\mathrm{N} 2 \mathrm{~K} 1$ and 8.50 was recorded with $\mathrm{N} 1 \mathrm{~K} 1, \mathrm{~N} 3 \mathrm{~K} 1, \mathrm{~N} 1 \mathrm{~K} 2$, $\mathrm{N} 3 \mathrm{~K} 2$ and lowest of 8.25 in N2K2.

The data presented in Table 2 revealed that maximum day (9.25) to germination was recorded with $\mathrm{N} 2$ followed by 8.5 days in $\mathrm{N} 3$ \& 8.13 days in $\mathrm{N} 1$.

Application of different doses of potash took 8.92 days to germination in $\mathrm{K} 1 \& 8.3$ days to germination in $\mathrm{K} 2$. With respect to the interaction effect maximum days to germination was recorded with N2 K1 (9.75) followed by 9.0 days to germinate in $\mathrm{N} 3 \mathrm{~K} 1$, 8.75 days to germinate in $\mathrm{N} 2 \mathrm{~K} 2,8.25$ days to germinate in $\mathrm{N} 1 \mathrm{~K} 1 \& 8.0$ days to germinate in N1K1 \& N3K2. 
Int.J.Curr.Microbiol.App.Sci (2018) 7(12): 155-161

Table.1 Days to germination (line sowing)

\begin{tabular}{|r|c|c|c|}
\hline \multicolumn{3}{|c|}{ Mean table } \\
\hline & K1 & K2 & Mean \\
\hline N2 & 8.50 & 8.50 & 8.50 \\
\hline N3 & 8.75 & 8.25 & 8.50 \\
\hline Mean & 8.50 & 8.50 & 8.50 \\
\hline
\end{tabular}

\begin{tabular}{|l|c|c|c|c|}
\hline & & $\mathrm{N}$ & $\mathrm{K}$ & $\mathrm{N} \times \mathrm{K}$ \\
\hline & Sem & 0.437 & 0.309 & 0.535 \\
\hline $\mathrm{NS}$ & $\mathrm{CD} 5 \%$ & 1.316 & 0.931 & 1.612 \\
\hline $\mathrm{NS}$ & $\mathrm{CV} \%$ & 16.78 & & \\
\hline
\end{tabular}

Table.2 Days to germination (broadcasting)

\begin{tabular}{|c|c|c|c|c|}
\hline \multicolumn{5}{|c|}{ Mean table } \\
\hline & K1 & & K2 & Mean \\
\hline N1 & 8.00 & & 8.25 & 8.13 \\
\hline $\mathrm{N} 2$ & 9.75 & & 8.75 & 9.25 \\
\hline N3 & 9.00 & & 8.00 & 8.50 \\
\hline Mean & 8.92 & & 8.3 & \\
\hline & & $\mathrm{N}$ & K & $\mathrm{N} \times \mathrm{K}$ \\
\hline & Sem & 0.214 & 0.151 & 0.262 \\
\hline S & CD 5\% & 0.645 & 0.456 & 0.790 \\
\hline S & $\mathrm{CV} \%$ & 8.11 & & \\
\hline
\end{tabular}

Table.3 Germination percentage (line sowing)

\begin{tabular}{|r|c|c|c|}
\hline \multicolumn{3}{|c|}{ Mean table $(\%)$} \\
\hline N1 & K1 & K2 & Mean \\
\hline N2 & 88.55 & 89.38 & 88.96 \\
\hline N3 & 90.78 & 89.85 & 90.31 \\
\hline Mean & 86.85 & 90.55 & 88.70 \\
\hline
\end{tabular}

\begin{tabular}{|c|c|c|c|c|}
\hline & & $\mathrm{N}$ & $\mathrm{K}$ & $\mathrm{N} \mathrm{x} \mathrm{K}$ \\
\hline & Sem & 1.664 & 1.176 & 2.038 \\
\hline NS & CD 5\% & 5.014 & 3.546 & 6.141 \\
\hline NS & CV \% & 6.08 & & \\
\hline
\end{tabular}


Int.J.Curr.Microbiol.App.Sci (2018) 7(12): 155-161

Table.4 Germination percentage (broadcasting)

\begin{tabular}{|r|c|c|c|}
\hline & \multicolumn{3}{|c|}{ Mean table (\%) } \\
\hline N1 & K1 & K2 & Mean \\
\hline N2 & 85.50 & 84.38 & 84.94 \\
\hline N3 & 84.05 & 84.98 & 84.51 \\
\hline Mean & 84.55 & 85.83 & 85.19 \\
\hline
\end{tabular}

\begin{tabular}{|c|l|c|c|c|}
\hline & & $\mathrm{N}$ & $\mathrm{K}$ & $\mathrm{N} \times \mathrm{K}$ \\
\hline & Sem & 2.664 & 1.884 & 3.263 \\
\hline NS & CD 5\% & 8.030 & 5.678 & 9.835 \\
\hline NS & CV \% & 10.25 & & \\
\hline
\end{tabular}

Table.5 Height of plant after 30 days (line sowing)

\begin{tabular}{|r|c|c|c|}
\hline \multicolumn{3}{|c|}{ Mean table $(\mathrm{cm})$} \\
\hline & K1 & K2 & Mean \\
\hline N1 & 13.48 & 16.38 & 14.93 \\
\hline N2 & 14.25 & 16.75 & 15.50 \\
\hline N3 & 15.40 & 17.48 & 16.44 \\
\hline Mean & 14.38 & 16.87 & \\
\hline
\end{tabular}

\begin{tabular}{|c|c|c|c|c|}
\hline & & $\mathbf{N}$ & $\mathbf{K}$ & $\mathbf{N} \mathbf{x}$ \\
\hline & Sem & 0.436 & 0.308 & 0.534 \\
\hline NS & CD 5\% & 1.314 & 0.929 & 1.609 \\
\hline S & CV \% & 9.11 & & \\
\hline
\end{tabular}

Table.6 Height of plant after 30days (broadcasting)

\begin{tabular}{|c|c|c|c|}
\hline \multicolumn{3}{|c|}{ Mean table $(\mathrm{cm})$} \\
\hline & K1 & K2 & Mean \\
\hline N1 & 14.95 & 16.63 & 15.79 \\
\hline N2 & 16.20 & 16.40 & 16.30 \\
\hline N3 & 16.08 & 18.38 & 17.23 \\
\hline Mean & 15.74 & 17.13 & \\
\hline
\end{tabular}

\begin{tabular}{|l|l|l|l|l|}
\hline & & $\mathbf{N}$ & $\mathbf{K}$ & $\mathbf{N ~ x ~ K}$ \\
\hline & Sem & 0.465 & 0.329 & 0.570 \\
\hline NS & CD 5\% & 1.402 & 0.992 & 1.717 \\
\hline
\end{tabular}


Int.J.Curr.Microbiol.App.Sci (2018) 7(12): 155-161

Table.7 Height of plant after 35days (line sowing)

\begin{tabular}{|c|c|c|c|}
\hline \multicolumn{3}{|c|}{ Mean table $(\mathrm{cm})$} \\
\hline & K1 & K2 & Mean \\
\hline N1 & 18.33 & 20.50 & 19.41 \\
\hline N2 & 18.38 & 20.40 & 19.39 \\
\hline N3 & 20.68 & 22.20 & 21.44 \\
\hline Mean & 19.13 & 21.03 & \\
\hline
\end{tabular}

\begin{tabular}{|l|c|c|c|c|} 
& & $\mathrm{N}$ & $\mathrm{K}$ & $\mathrm{N} \times \mathrm{K}$ \\
\hline & $\mathrm{Sem}$ & 0.544 & 0.385 & 0.667 \\
\hline $\mathrm{NS}$ & CD 5\% & 1.641 & 1.160 & 2.009 \\
\hline $\mathrm{S}$ & CV \% & 8.85 & & \\
\hline
\end{tabular}

Table.8 Height of plant after 35days (broadcasting)

\begin{tabular}{|c|c|c|c|}
\hline \multicolumn{4}{|c|}{ Mean table $(\mathrm{cm})$} \\
\hline & K1 & K2 & Mean \\
\hline N1 & 19.20 & 21.63 & 20.41 \\
\hline N2 & 20.85 & 22.73 & 21.79 \\
\hline N3 & 20.50 & 23.33 & 21.91 \\
\hline Mean & 20.18 & 22.56 & \\
\hline
\end{tabular}

\begin{tabular}{|c|c|c|c|c|} 
& & N & K & N x K \\
\hline & Sem & 0.644 & 0.456 & 0.789 \\
\hline NS & CD 5\% & 1.942 & 1.373 & 2.378 \\
\hline NS & CV \% & 9.85 & & \\
\hline
\end{tabular}


From the data tabulated and presented in Table 3 revealed that highest (90.31) percentage of seed germination was recorded in $\mathrm{N} 2$ followed by $88.96 \%$ in N1 \&88.70\% in N3. With respect to application of potash, maximum germination $(89.92 \%)$ was recorded in $\mathrm{K} 2$ followed by $\mathrm{K} 1$ $(88.73 \%)$. So far the interaction between nitrogen \& potash was concerned, maximum percentage of seed germination $(90.78 \%)$ was found in $\mathrm{N} 2 \mathrm{~K} 1$ followed by $\mathrm{N} 3 \mathrm{~K} 2(90.55 \%)$, N2K2 $(89.85 \%), \mathrm{N} 1 \mathrm{~K} 2(89.39 \%) \& 86.85 \%$ in N3 K1.

Application of different doses nitrogen recorded varied germination percentage in broadcasting of coriander seeds. Highest germination percentage $(84.94 \%)$ was recorded with N1 application followed by $85.19 \%$ in N3 \& $84.51 \%$ in N2 (Table 4). So far as Potash application was concerned $85.06 \%$ of germination was recorded in $\mathrm{K} 2$ followed by $84.70 \% \mathrm{Ki}$. In interaction effect with nitrogen and potash highest percentage of germination $(85.83 \%)$ recorded with $\mathrm{N} 3 \mathrm{~K} 2,85.50$ in N1K1, 84.98 in N2K2 and 84.05 in N2K1.

The height of the plant was recorded after thirty days and from the mean tabulation value it was founded that the height of the plant was maximum $(16.44 \mathrm{~cm})$ with $\mathrm{N} 3$, followed by $15.50 \mathrm{~cm}$ in N2\&14.93 $\mathrm{cm}$ in N1 (Table 5). So, far application of potash K2 recorded plant height of $16.87 \mathrm{~cm}$ followed by $\mathrm{K} 1$ which recorded $14.38 \mathrm{~cm}$ plant height. From the interaction effect it was found that N3 K2 recorded a plant height of $17.48 \mathrm{~cm}$, followed by $16.75 \mathrm{~cm}$ in $\mathrm{N} 2 \mathrm{~K} 2, \quad 16.38 \mathrm{~cm}$ in $\mathrm{N} 1 \mathrm{~K} 2 \& 15.40 \mathrm{~cm}$ in $\mathrm{N} 3 \mathrm{~K} 1 \& 14.25 \mathrm{~cm}$ in N2K1. $\mathrm{N} 1 \mathrm{~K} 1$ recorded the lowest plant height of 14.38 $\mathrm{cm}$.

It was revealed from the tabulated data that the height of the plant was $17.23 \mathrm{~cm}$ in $\mathrm{N} 3$, followed by in $16.30 \mathrm{~cm} \mathrm{~N} 2$ and $15.79 \mathrm{~cm} \mathrm{~N} 1$ (Table 6). With respect to application of Potash $17.3 \mathrm{~cm}$ plant height was recorded in $\mathrm{K} 2$ followed by $15.74 \mathrm{~cm}$ in K1.In interaction effect it was found from the tabulated data that $18.38 \mathrm{~cm}$ was recorded with $\mathrm{N} 3 \mathrm{~K} 2$, followed by
$16.63 \mathrm{~cm}$ in $\mathrm{N} 1 \mathrm{~K} 2,16.40 \mathrm{~cm}$ in $\mathrm{N} 2 \mathrm{~K} 2,16.20$ $\mathrm{cm}$ in $\mathrm{N}_{2} \mathrm{~K}_{1}, 16.08 \mathrm{~cm}$ in $\mathrm{N}_{3} \mathrm{~K}_{1}$ \& the minimum of $14.95 \mathrm{~cm}$ in $\mathrm{N}_{1} \mathrm{~K}_{1}$.

It was found that height of plant was less in line sowing as compared to broadcasting. The height of the plan was maximum $(21.44 \mathrm{~cm})$ in $\mathrm{N} 3$ followed by $19.41 \mathrm{~cm}$ in $\mathrm{N} 1 \& 19.39 \mathrm{~cm}$ in $\mathrm{N} 2$ (Table 7). Due to varied dose of potash plant height was found to be $21.03 \mathrm{~cm}$ with $\mathrm{K} 2$ $\& 19.13 \mathrm{~cm}$ in K1.In the interaction effect plant height of $22.20 \mathrm{~cm}$ was recorded with N3K2 followed by $20.68 \mathrm{~cm}$ in $\mathrm{N}_{3} \mathrm{~K}_{1} 20.50 \mathrm{~cm}$ in $\mathrm{N}_{1} \mathrm{~K}_{2}, 20.40 \mathrm{~cm}$ in $\mathrm{N}_{2} \mathrm{~K}_{2}$ and the lowest height of $18.33 \mathrm{~cm}$ in $\mathrm{N}_{1} \mathrm{~K}_{1}$.

Due to broadcasting of Coriander seeds a plant height of $21.91 \mathrm{~cm}$ was recorded in N3, followed by $21.79 \mathrm{~cm}$ in N2 \& $20.41 \mathrm{~cm} \mathrm{~N} 1$ after 35 days of sowing (Table 8). Due to Potash application $22.56 \mathrm{~cm}$ plant height was recorded in $\mathrm{K} 2$ followed by $20.18 \mathrm{~cm}$ in $\mathrm{K} 1$. Due to Interaction effect plant height of 23.33 $\mathrm{cm}$ was recorded with $\mathrm{N} 3 \mathrm{~K} 2$ which was the highest Plant height of $22.73 \mathrm{~cm}$ was recorded with $\mathrm{N} 2 \mathrm{~K} 2,21.63 \mathrm{~cm}$ with $\mathrm{N} 1 \mathrm{~K} 2,20.85 \mathrm{~cm}$ with N2K1 \& $20.50 \mathrm{~cm}$ with N3K1. Lowest plant height of $19.20 \mathrm{~cm}$ was obtained with N1K1.

Days to germination \& germination percentage of coriander seeds due to line sowing \& broadcasting did not varied significantly due to different doses of Nitrogen \& Potassium application. Maximum days to germination (8.75) was found with $\mathrm{N} 2 \mathrm{~K} 1$ in line sowing \& highest percentage of seed germination (90.75) was found in line sowing with N3K2\&85.06\% in $\mathrm{N} 3 \mathrm{~K} 2$ in broadcasting of seeds. Application of different doses of nitrogen and potash did not influence much the days to germination and germination percentage. The result revealed that plant height in coriander was influenced by application of Nitrogen, Potash and due to their combined effect both in line sowing \& in broadcasting. In both the cases higher doses of potash has increased the plant height \& in combination of Nitrogen \& Potash highest plant height of $17.48 \mathrm{~cm}$ in $\mathrm{N} 3 \mathrm{~K} 2 \& 18.38 \mathrm{~cm}$ in 
N3K2 was recorded in line sowing \& broadcasting respectively. Increase in plant height along with branches is a desirable character to make the plant more bushy and also thereby increase in yield. Increase in plant height due to varied doses and their combination might be due to the production of more chlorophyll, photosynthates, phytohormones and cytokinin which are utilized by the plant during growth \& development helping cell formation \& elongation. Increase in plant height due to varied nutrition was also reported by Raghavaiash et al., (1985), Bhati (1988) and Pawar et al., (2007).Combined effect of nitrogen and potash resulted in the production of maximum number of branches as compared to Nitrogen \& Potash alone both in line sowing \& broadcasting. Due to increase in nutrient efficiency and synergistic effect of nitrogen $\&$ potash there is increase in number of primary branches per plant which was also reported by Pawar et al., (2007), Patel et al., (2013) and Shanu et al., (2013). Due to interaction effect number of primary branches was 6.50 under $\mathrm{N} 3 \mathrm{~K} 2$ in line sowing in which the first leaf appeared at a height of $16.60 \mathrm{~cm}$ as compared to $15.80 \mathrm{~cm}$ in $\mathrm{K} 2 \& 15.30$ in $\mathrm{N} 2$ which indicate that combined application influenced the production of primary branches and also resulted in increase in length at which first leaf appear in the plant was also reported by Patel et al., (2013).Length of root \& weight of root \& weight of plant. Due to varied combination of Nitrogen \& Potash root length of $9.50 \mathrm{~cm}$ was recorded in $\mathrm{N} 3 \mathrm{~K} 1 \& 9.26 \mathrm{~cm}$ in $\mathrm{N} 2$. The change in root length many a times is an important factor in deciding the yield of a crop. Application of combined source of nutrition that is Nitrogen \& Potash influenced the root length.

It was concluded that the maximum growth was observed in $\mathrm{N} 3 \mathrm{~K} 2$ treatment in line sowing practice. Hence it may be recommended for farmers to get maximum return with minimum use of inputs.

\section{References}

Bhati, M. S., Dixit, B. S. and Bhati, D. S., (1988). Effect of nitrogen and stage of umbel picking on growth and nitrogen uptake of fennel. Haryana J. Agron, 4 (1): 51-52.

Patel, C.B., Amin, A.U. and Patel, A.L. (2013). Effect of varying levels of nitrogen and sulphur on growth and yield of coriander (Coriandrum sativum L.). The Bioscan, (4): 1285-1289.

Pawar, P.M., Naik, D.M., Damodhar, V.P., Shinde, V.N. and Bhalerao, R.V.L. (2007). Influence of graded levels of spacing and nitrogen on growth and yield of coriander (Corianderum sativum L.). The Asian J. of Hort., 2(1): 58-60.

Raghavaiash, V. R., Reddy, P.S., Rao, D.S. K. and Ramaiash, K. (1985). Response of coriander varieties to nitrogen fertilization. South Indian Hort., 33: 341343.

Shanu, I.S., Naruka, P.P., Singh, R.P., Shaktawat, S and Verma, K.S. (2013). Effect of seed treatment and foliar spray of thiourea on growth, yield and quality of coriander (Coriandrum sativum L.) under different irrigation levels. International J. seed spices, 3(1): 20-25.

\section{How to cite this article:}

Mishra, S.P., A.K. Padhiary, A. Nandi and Patnaik, A. 2018. Effect of Nitrogen and Potash on Growth of Coriander (Var. Super Midori). Int.J.Curr.Microbiol.App.Sci. 7(12): 155-161. doi: https://doi.org/10.20546/ijcmas.2018.712.020 